\title{
Tracheostomy tube change during the COVID-19 pandemic: timing and safety considerations
}

\author{
Mohamed Zahran* (D) and Ahmed Youssef
}

\begin{abstract}
Background: The recent outbreak of SARS-CoV-2 has become pandemic since it began in late 2019. Tracheostomy is considered an aerosol-generating procedure which increases potential viral exposure to the health care staff.

Main body: Since many patients diagnosed with SARS-CoV-2 underwent tracheostomy, the need for a standardized practice for tracheostomy tube change and care is mandatory. Articles listed in PubMed and guidelines from the otolaryngology societies were reviewed, and the state-of-the-art practice related to the topic is highlighted.

Conclusions: Tracheostomy care in COVID-19 patients requires significant decision-making and preparation to carry out the task in a safe way and eliminate the risk of viral transmission.
\end{abstract}

Keywords: Coronavirus, COVID-19, Tracheostomy, Personal protective equipment

\section{To the Editor}

\section{Background}

The recent outbreak of SARS-CoV-2 has become pandemic since it began in late 2019 [1]. Due to the high virulence via aerosol transmissions, to date, COVID-19 has infected more than 7 million people all over the world, causing more than 400,000 confirmed deaths [2]. Tracheostomy is an aerosol-generating procedure and increases potential viral transmission to the health care team [3]. As many COVID-19-positive patients underwent tracheostomy, the need for a standardized practice for tracheostomy tube change and care became mandatory. Reducing the risk of nosocomial infections through transmission of COVID-19 to other patients and health care workers is of critical importance [4].

\footnotetext{
* Correspondence: abdelnaby00@hotmail.com

Department of Otolaryngology, Faculty of Medicine, Alexandria University School of Medicine, Champllion Street, El-Azareeta, Alexandria, Egypt
}

\section{Main text}

Articles listed in PubMed and guidelines from the AAOHNS, ENT-UK, and French Society of Otolaryngology (SFORL) were reviewed, and the state-of-the-art practice related to the topic is highlighted.

\section{Ethical considerations}

The Ethics Committee at the University Hospital approved this study, and informed consent was not mandatory.

The up to date information and practice guidelines are presented in the following sections.

\section{COVID-19 confirmed \\ Timing of tracheostomy cannula change}

1. Both AAO-HNS and ENT-UK recommend no change of the tracheostomy tube until COVID-19 testing is negative and will have to review with infectious diseases.

2. Other authors recommend that the first tracheostomy change can be done after 7-10 days and subsequent change can be delayed 30 days after [5].

\section{Springer Open}

( ) The Author(s). 2020 Open Access This article is licensed under a Creative Commons Attribution 4.0 International License, which permits use, sharing, adaptation, distribution and reproduction in any medium or format, as long as you give appropriate credit to the original author(s) and the source, provide a link to the Creative Commons licence, and indicate if changes were made. The images or other third party material in this article are included in the article's Creative Commons licence, unless indicated otherwise in a credit line to the material. If material is not included in the article's Creative Commons licence and your intended use is not permitted by statutory regulation or exceeds the permitted use, you will need to obtain permission directly from the copyright holder. To view a copy of this licence, visit http://creativecommons.org/licenses/by/4.0/. 


\section{Technical considerations and safety precautions}

Place of the procedure Tracheal cannula management must be performed in a BSL-3 (biosafety level 3) [6] setting which is nowadays the standard for regular ward and ICUs (intensive care units) hosting COVID-19positive patients [5].

Pre-procedure preparation Surgical hand scrub must be done before and after each treatment. Dressing and undressing must be done within the room. The standard PPE (personal protective equipment) consists of an apron or a gown, head protection with a hood cap, N95 mask, protective glasses, and non-sterile gloves. The surgeon must ensure that all the necessary equipment are ready (correct size tracheostomy tube, suction catheters, lidocaine spray).

Details of the procedure If the patient is on mechanical ventilator, anesthetist should sedate the patient and perform a muscle relaxation to minimize risk of coughing and aerosol generation. Five percent lidocaine is sprayed into the tracheostomy tube to anesthetize the airway and prevent coughing. A cuffed non-fenestrated tracheostomy tube should be used. Safe disposition of all equipment that came in contact with the patient must be done.

Nursing care The tracheostomy care should be performed by trained nursing staff. The following is the state-of-the-art tracheostomy care:

- Suction should be done via closed circuit.

- Safe gentle suction and avoid unnecessary suctioning to reduce aerosolization.

- Cannula should be maintained appropriately inflated through regular checks of cuff pressure to avoid leak.

- Cannula should be held during any passive movement of the patient to avoid air leak from the stoma.

- Place HME (heat moisture exchange) with viral filter or a ventilator filter once the tracheotomy tube is disconnected from mechanical ventilation.

- Unnecessary dressing change should be avoided except if there is evidence of local infection [5].

These technical considerations in tracheostomy care are valid till there is documented evidence that the patient is recovered from COVID-19. The duration of contagiousness is still uncertain but is probably more than 25 days [7].

\section{COVID-19 unknown}

The need to confirm COVID-19 status

Tracheostomized patients constitute significant infectious risk due to high aerosol generation. Preoperative COVID-19 testing is highly recommended prior to tracheostomy for all patients during the current pandemic. If tracheostomy was done without confirmation of COVID-19 status, postoperative COVID-19 testing should be done [8].

\section{Precautions in unknown COVID-19 status}

This situation is present when the patient is at home or outpatient clinic and no recent diagnostic test for COVID-19 is available. The following precautions are mandatory: N95 mask, protective glasses, gown, cap, or hood cap. All disposable equipment that came in contact with the tracheostomy tube or trachea (suction catheters) must be disposed appropriately. The tracheostomy tube should be connected to an HME filter and covered by a surgical mask to minimize risk of aerosol generation and droplet exposure [9].

\section{Discussion}

Tracheostomy and tracheostomy care constitute a great risk for the medical staff due to aerosol generation. Several guidelines were recommended for the safety of the patients and caregivers. As many patients suffer from COVID-19 respiratory distress, the need for prolonged mechanical ventilation and tracheostomy care increases [1].

All the published guidelines recommend full PPE including N95 (USA), FFP2, or FFP3 (Europe) mask and the use of double gloves, goggles or eye protection, face shield, and an apron or gown [10-14]. The use of cuffed non-fenestrated tracheostomy tube was recommended by the American and Italian Otolaryngology guidelines. Additionally, both societies recommend that the cuff must be inflated all the time to avoid any air leak $[10,11]$. The AAO-HNS and the South African Otolaryngology Society recommended the use of HME with viral filter to prevent viral transmission [10, 12]. The use of closed suction circuit was recommended by the American, South African, and British Societies [10, 12, 13].

There were controversies among guidelines in regard to the timing for the first tracheostomy tube change. The AAO-HNS and the South African Society did not recommend tube change until the patient became negative $[10,12]$. In contrast, the Italian Society and ENTUK suggested the first change to occur after 7-10 days $[11,13]$. The Spanish guidelines advised to change tracheostomy tube after 14-21 days regardless of the COVID-19 status [14]. 


\section{Conclusions}

Although tracheostomy care was previously considered routine, it poses significant risk of viral exposure to health care staff and the community. The presented state-of-the-art practice is a guide for health practitioners involved in COVID-19 patients' care. Further evidence-based guidelines are needed in the near future as our understanding of this novel disease is evolving.

\section{Abbreviations}

AAO-HNS: American Academy of Otolaryngology-Head and Neck Surgery; BSL: Biosafety level; COVID-19: Coronavirus disease; HME: Heat moisture exchanger; ICU: Intensive care unit; PPE: Personal protective equipment; SARS-CoV-2: Severe acute respiratory syndrome caused by coronavirus 2

\section{Acknowledgements}

None

\section{Authors' contributions}

MZ: corresponding author; design of the study, data collection and interpretation, final approval of the manuscript. AY: data interpretation, manuscript drafting, revision, and approval.

\section{Funding}

None

\section{Availability of data and materials}

Not applicable

\section{Ethics approval and consent to participate}

The Ethics Committee at the University Hospital approved this study, and informed consent was not mandatory.

\section{Consent for publication}

Not applicable

\section{Competing interests}

None

Received: 1 June 2020 Accepted: 6 August 2020

Published online: 25 November 2020

\section{References}

1. Zhu N, Zhang D, Wang W et al (2020) A novel coronavirus from patients with pneumonia in China, 2019. N Engl J Med 382:727-733

2. World Health Organization (WHO). Coronavirus disease (COVID-19) pandemic.https://www.who.int/emergencies/diseases/novelcoronavirus2019

3. Patel ZM, Fernandez-Miranda J, Hwang PH, Nayak JV, Dodd R, Sajjadi H et al (2020) Letter: precautions for endoscopic transnasal skull base surgery during the covid-19 pandemic [published online ahead of print, $2020 \mathrm{Apr}$ 15]. Neurosurgery:nyaa125. https://doi.org/10.1093/neuros/nyaa125

4. Murthy S, Gomersall CD, Fowler RA (2020) Care for critically ill patients with covid-19. JAMA 323(15):1499-1500. https://doi.org/10.1001/jama.2020.3633

5. Pichi B, Mazzola F, Bonsembiante A et al (2020) CORONA-steps for tracheotomy in COVID-19 patients: a staff-safe method for airway management. Oral Oncol 105:104682

6. Chosewood LC, Wilson DE (eds) (2009) Biosafety in microbiological and biomedical laboratories, 5th edn. Centers for Disease Control and Prevention

7. Top KK-W, Tsang OT-Y, Leung W-S et al (2020) Temporal profiles of viral load in posterior oropharyngeal saliva samples and serum antibody responses during infection by SARS-CoV-2: an observational cohort study. Lancet Infect Dis. https://doi.org/10.1016/S1473-3099(20)30196-1

8. Shiba, T., Ghazizadeh, S., Chhetri, D., St. John, M., \& Long, J. Tracheostomy considerations during the COVID-19 pandemic. OTO Open 2020. doi.https:// doi.org/10.1177/2473974X20922528

9. Schultz P, Morvan JB, Fakhry N et al (2020) French consensus regarding precautions during tracheostomy and post-tracheostomy care in the context of COVID-19 pandemic [published online ahead of print, $2020 \mathrm{Apr}$ 9]. Eur Ann Otorhinolaryngol Head Neck Dis S1879-7296(20):30096-X
10. Parker N, Schiff B, Fritz M, Rapaport S, Schild S, Altman K et al (2020) Tracheotomy recommendations during the COVID-19 pandemic. Am Acad Otorhinolaryngol Head Neck Surg

11. Società Italiana di Otorinolaringoiatria (SIO). La Tracheostomia in Pazienti Affetti Da COVID-19:;2020. https://www.sioechcf.it/riassunto-linee-guida-latracheostomia-in-pazienti-affetti-da-covid-19/.

12. Winter S, Rocke J, Heward E (2020) Guidance for surgical tracheostomy and tracheostomy tube change during the COVID-19 pandemic. South Afr Soc Otorhinolaryngol Head Neck Surg

13. ENT-UK Guideline. https://www.entuk.org/tracheostomy-guidance-duringcovid-19-pandemic.

14. Recomendaciones de la SECOMCYC en relación con la cirugía y COVID-19. http://www.secom.org/wp-content/uploads/2020/03/2.-RECOMENDACIONESSECOMCYC-TRAQUEOTOMIA-EN-COVID-19-1.pdf. [article in Spanish]

\section{Publisher's Note}

Springer Nature remains neutral with regard to jurisdictional claims in published maps and institutional affiliations.

\section{Submit your manuscript to a SpringerOpen ${ }^{\circ}$ journal and benefit from:}

- Convenient online submission

- Rigorous peer review

- Open access: articles freely available online

- High visibility within the field

- Retaining the copyright to your article

Submit your next manuscript at $\boldsymbol{\nabla}$ springeropen.com 